\title{
COMPARATIVE ASSESSMENT OF GROUNDWATER QUANTITY USING GIS FOR CHENNAI METRO RAIL CORRIDOR, TAMIL NADU, INDIA
}

\author{
LILLY, R. $^{1^{*}}-$ RAVIKUMAR, G. $^{2}$ \\ ${ }^{I}$ Department of Civil Engineering, Anna University \\ Chennai 600025, Tamil Nadu, India \\ ${ }^{2}$ Centre for Water Resources, Department of Civil Engineering, Anna University \\ Chennai 600025, Tamil Nadu, India \\ e-mail: grk6617@gmail.com,phone: +91-9840-257-426 \\ *Corresponding author \\ e-mail: lillypuppu@gmail.com; phone: +91-9884-659-759 \\ (Received $8^{\text {th }}$ Mar 2017; accepted $20^{\text {th }}$ May 2017)
}

\begin{abstract}
This paper aims to compare the water quantity availability before and after the construction of the Chennai metro rail corridor in Tamil Nadu, India. Data relating to water levels from eight observation wells were collected for a period of 20 years, i.e., from 1995 to 2014. The construction of metro rail started in the year 2008 and the data were divided into two phases, namely 1995-2007 and 2008-2014 i.e., before and after the construction of metro rail. The volume of water was calculated for each phase using Geographical Information System (GIS). Rasterizied data such as specific yield of the various soil types covering the study area, water table levels and the shape area of the study were used. For calculation, the calculated values of water quantity for each and every year were mapped, the mean values for 1995-2007 and 2008-2014 were found and the mapping was used to compare the existing water quantity scenario in the metro rail corridor.
\end{abstract}

Keywords: water quantity, GIS, specific yield, spatial distribution, rasterization, groundwater

\section{Introduction}

Urbanization in any form will have both positive and negative impacts in equal measures. The prevalent water problems like quantity shortage, environment pollution and ecological damage restrict urban sustainable development (Cui et al., 2009). In India pollution and over extraction are important components of the groundwater problem (Rajamanickam et al., 2010) Historically, a distinct separation in the consideration of water quantity and water quality concerns has been in existence, with most of the attention being given to the provision of required quantities.(Jat et al., 2005). In urban areas, available surface water resources are generally inadequate to satisfy the entire water requirements. So the reliance on ground water has increased over the years. In most of the states in India, withdrawal of groundwater for both agricultural and industrial use has been more than what can be recharged (Yoo et al., 2007).

Metro rail construction is a massive contribution towards urbanization which involves tunneling for underground construction. The tunneling assignment of the Chennai metro in Tamil Nadu, India is considered as one of the most complicated jobs due to the complex soil structure. The water table in Chennai too is very high. During the rainy season it reaches almost ground level. Hence, tunneling becomes a highly complicated job. All these factors lead to changes in the water table. 
Tunneling results in ground water drawdown and impacts the ground settlements. Tunneling beneath the ground water table causes a state of stress and pore water pressure distribution (Han et al., 2005). Hence the assessment of water levels becomes the subject matter for this study.

\section{Geographic Information System (GIS)}

Geographical Information System (GIS) based groundwater studies were focused on the preparation of hydrogeomorphological maps, interpretation of lineaments and integrated terrain analysis (Goodchild et al., 1993) Data is the core and emphasis of geographical information system (GIS) (Wei et al., 2003). Remote Sensing, GIS and other assessment techniques have been in use for a long time now to study groundwater in terms of its movement, quantity, and quality (Wang et al., 2011). GIS is a comprehensive system of figure data management, attribute data management and spatial data analysis based on computer. It is a new research area that synthesizes computer science, management science, information science, spatial science, geology, environment science and others (Ravikumar et al., 2005). Introduction of GIS techniques for ground water research followed by analysis of the features and regulations for ground water field through informational and visual modeling is a new trend (Cui et al., 2009).

\section{Literature Review}

Shukla (2014) derived the groundwater potential zones for the entire basin of river tons in Allahabad district, Uttar pradesh, India, using GIS and remote sensing techniques. Various thematic layers such as base map, drainage map, counter map, geology map have been prepared using Arc GIS 9.3 software. These thematic layers have been integrated on GIS environment through assigning proper weight to various factors controlling occurrence of groundwater. As a result, groundwater potential zones map obtained, classifies the study area into zones such as very good, good, moderate, poor and very poor.

Jasmin et al. (2015) developed groundwater potential index (GWPI) map of the Araniar river basin, India, through an overlay analysis of climatic, geologic, geomorphic, soil and land use/land cover features of the basin using Landsat 5 Thematic Mapper (TM) data and ArcGIS 9.2. Correlation analysis was carried out for rainfall, geology, soil, slope, geomorphology and land use/land cover maps being overlaid with standardized weights of $0.49,0.20,0.17,0.05,0.05$, and 0.04 and maximum correlation coefficient of 0.922 was obtained. The GWPI map showed groundwater potential zones as "excellent", "very good", "good", "moderate" and "poor" with yield values in the ranges 293-361, 210-292, 126-209, 43-125, and 15-42 lpm, respectively.

Riad et al. (2011) were interested in finding the locations for artificial recharge of groundwater. The technique was applied on Sadat Industrial City which is located in a semi arid area in the western desert fringes of the Nile delta in the north west of Egypt. Thematic layers for number of parameters were prepared from some maps and satellite images and they were classified, weighted and integrated in ArcGIS environment. By means of the overlay weighted model in ArcGIS a suitability map which was classified into a number of priority zones was obtained and it could be compared with the obtained true-false map of boolean logic. This study recommended Boolean logic as a 
first estimator for locating the best locations as it is easier and not time consuming, while the overlay weighted model for more accurate results.

Navarro-Solís et al. (2016) proposed an integrated methodology to define the flow patterns governing the movement of groundwater in a semiarid region of Mexico. The methodology incorporated hydrogeochemical characterization with the application of flow systems theory, the behaviour of arsenic and fluoride as indicators of the quality for human consumption and a correlation matrix to identify potential areas of rechargedischarge; these variables were grouped in GIS. The results explained the movement of groundwater influenced by the dissolution of silicates with the geochemical evolution of arsenic under two natural conditions, whereas fluoride exhibited two situations, one natural and the other anthropogenic.

Bonansea et al. (2016) classified land use and land cover (LULC) in the Natural forest of Rio Tercero watershed (Argentina).The relationship was related to nutrient loading in the watershed with the land use and land cover map. Statistical analyses were carried out to identify relationships between water quality and LULC. Results suggested that urban and agricultural activities were the primary driving forces behind the variations in nutrient loads measured in tributaries. Sub-watershed most affected by human activities displayed the highest values of nutrient loads.

Ravikumar et al. (2005) developed a model in lumped approach with limited data for a better understanding of ground water potentia. This study was carried out in Ambur sub-watershed of Upper Palar basin in Vellore district in Tamil Nadu, India. GIS software was used to create a spatial database and to analyze the data using overlaying techniques. The conclusion was that this method could be used effectively for speeder estimation of ground water quantity with reasonable accuracy.

Jat et al. (2009) made estimates of quantitative and qualitative impacts of groundwater resulting from urbanization in Ajmeer, a major city of Rajasthan. Groundwater recharge was computed using the water level fluctuation method. Database related to urbanization and groundwater was created in GIS and the temporal and spatial variations in groundwater quality and quantity were correlated with urban growth, using overlay analysis GIS. Watershed approach was used for the estimation of the groundwater recharge and delineated using GIS. Average recharge from the area was found to be $3.06 \%$.

Marufur Rahman et al. (2012) made computation of changes in groundwater level with expansion of irrigation in Bangladesh. Secondary data was mainly used for this study. Hydrograph analysis, groundwater level mapping, groundwater depletion rate calculation were done from groundwater level observation well data found to be provided by Bangladesh Water Development Board (BWDB) and Barind Multipurpose Development Authority (BMDA). Mapping software ArcGIS 9.3.1 was used for mapping. As a result, the difference between the maximum and the minimum water levels in one season was found to be $2.67 \mathrm{ft}$. The average value of yearly maximum rate of depletion and minimum rate of depletion was seen as 1.04 feet / year.

\section{Study Area}

Chennai (formerly Madras), is the fourth largest metropolitan city in India. There has been a steep increase in population in recent years, with enhanced reliable and safe transportation needs.Chennai district enjoys a tropical climate with mean annual temperature of 24.3 to $32.9^{\circ} \mathrm{C}$. The temperature is usually in the range $13.9-45^{\circ} \mathrm{C}$. 
The metro rail corridors have been digitized along with metro stations and river sources like Adyar and Coovam rivers. The observational well points are located in the study area using GIS shown in Figure 1.

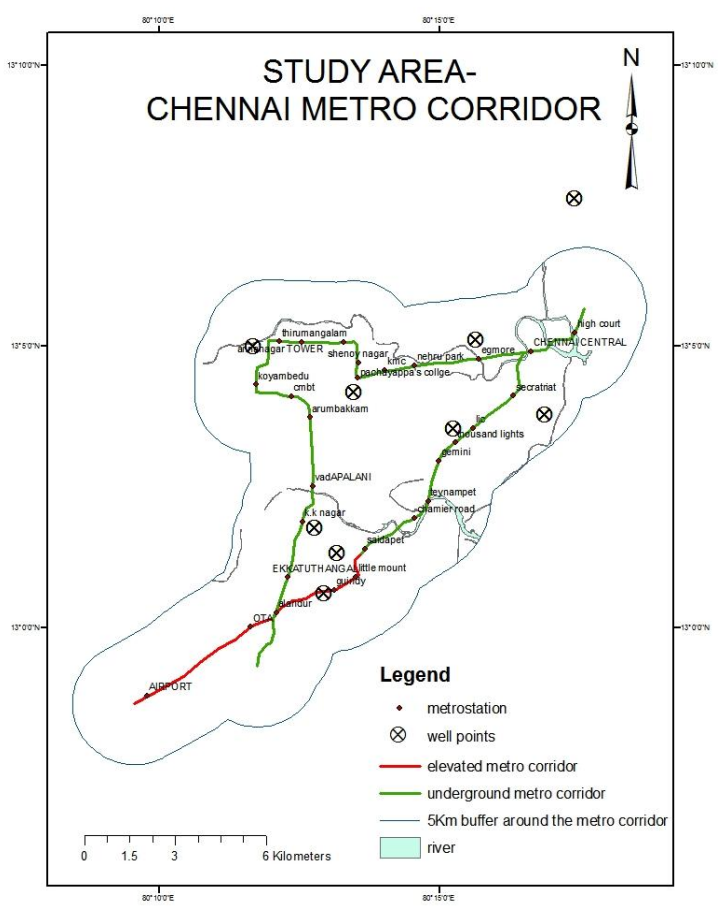

Figure 1. Study area with observation well of Chennai metro rail corridor, Tamil Nadu, India

\section{Results}

\section{Slope map for study area}

Chennai district forms part of coastal plains of Tamil Nadu. A major part of the district has a flat topography with a very gentle slope towards east. The altitudes of land surface vary from $10 \mathrm{~m}$ above MSL in the west to sea level in the east. Fluvial, marine and erosion landforms are noticed in the district. The statement is proved by mapping the elevation levels of the selected locations of the area and it is shown in Figure 2 and the elevation values are tabulated in Table 1.

Table 1. Locations with elevation

\begin{tabular}{c|c|c}
\hline Serial Number & Location & Elevation \\
\hline 1 & Tandiarpet & 12 \\
\hline 2 & Vepery & 12 \\
\hline 3 & Chepauk & 13 \\
\hline 4 & Lights & 13 \\
\hline 5 & Saidapet & 15 \\
\hline 6 & Guindy & 15 \\
\hline 7 & Aminjikarai & 15 \\
\hline 8 & Tirumangalam & 15 \\
\hline 9 & Vadapalani & 18.5 \\
\hline 10 & K.K.Nagar & 16 \\
\hline 11 & Airport & 15 \\
\hline
\end{tabular}




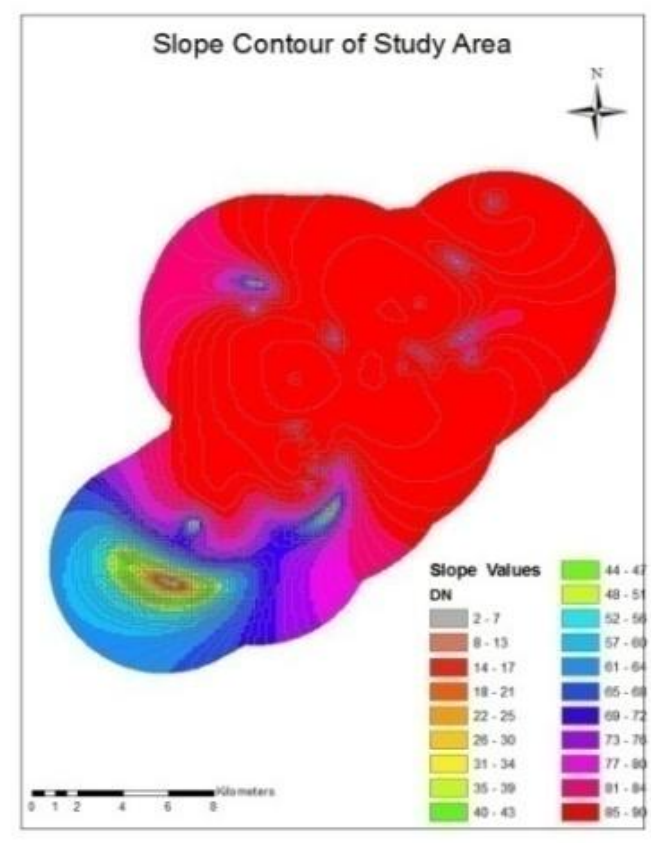

Figure 2. Slope contour of study area

The contour map shows that the values are higher in the North and gradually reduce towards to the East. Hence, the study area has a gentle slope from North to East.

\section{Rainfall pattern}

Rainfall data were collected for a study of the rainfall pattern in the study area. The water table levels before and after the construction were analyzed along with the rainfall data. The analysis helped to determine the tunneling effect on water table levels. The rainfall data are plotted and shown in the Graph 1.

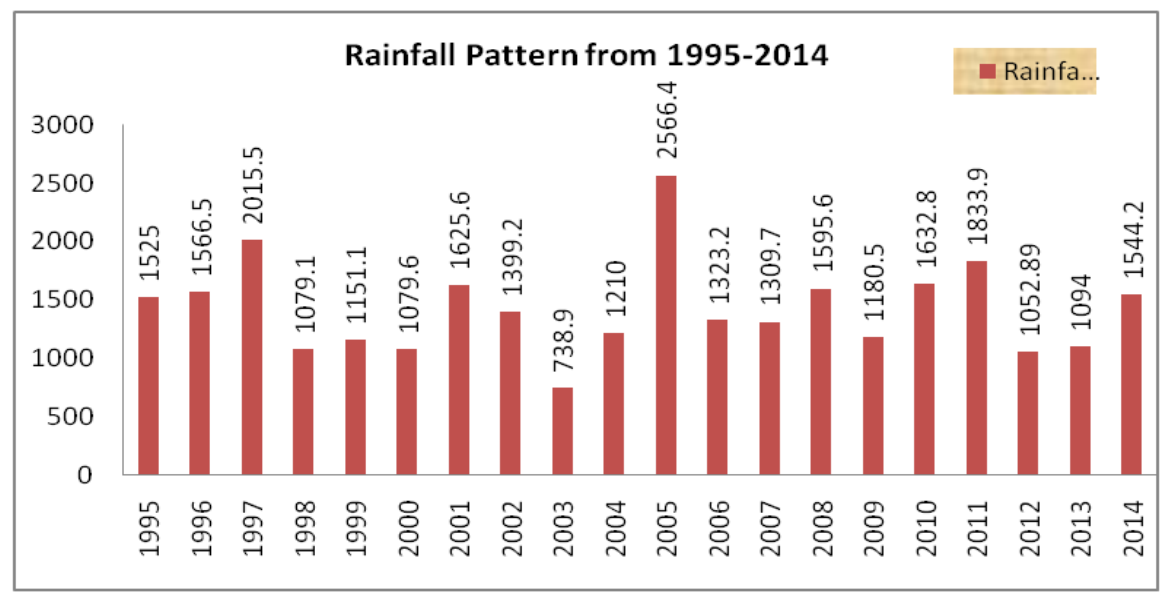

Graph 1. Rainfall data from 1995 to 2014

The mean rainfall for the period 1995-2007 was found to be $1429.98 \mathrm{~mm}$ and $1419.13 \mathrm{~mm}$ for $2008-2014$. The rainfall distribution variation between the two periods 
is very small, and shows that reduction in ground water level is not due to decreased rainfall. It was rather the underground work that caused a change in the ground water volume.

\section{Water table levels}

Data were collected for the period 1995-2014 from Centre Ground Water Board and the Institute of Water Studies, Chennai, and the data were separated into 1995-2007 and 2008-2014, that is, before and after the construction of metro rail corridor. The mean values of the water levels were calculated for 1995-2007 and 2008-2014. These values are tabulated in the Excel spread sheet with the location of observation wells in and around the metro rail corridor and shown in Tables 2, 3, and 4.

The comparison of mean water table levels for the observation wells for the periods 1995-2007 and 2008-2014 was plotted and is shown in Graph 2.The graph clearly shows that in Tondiarpet, Vepery, Chepauk, and Thousand Lights the water table level has gone down after the construction. In Saidapet,Guindy, Amnijikarai, Tirumangalam and K. K. Nagar the water table level shows increase in underground.This scenario of rise and fall of the ground water table is purely due to the underground work undertaken for metro rail.

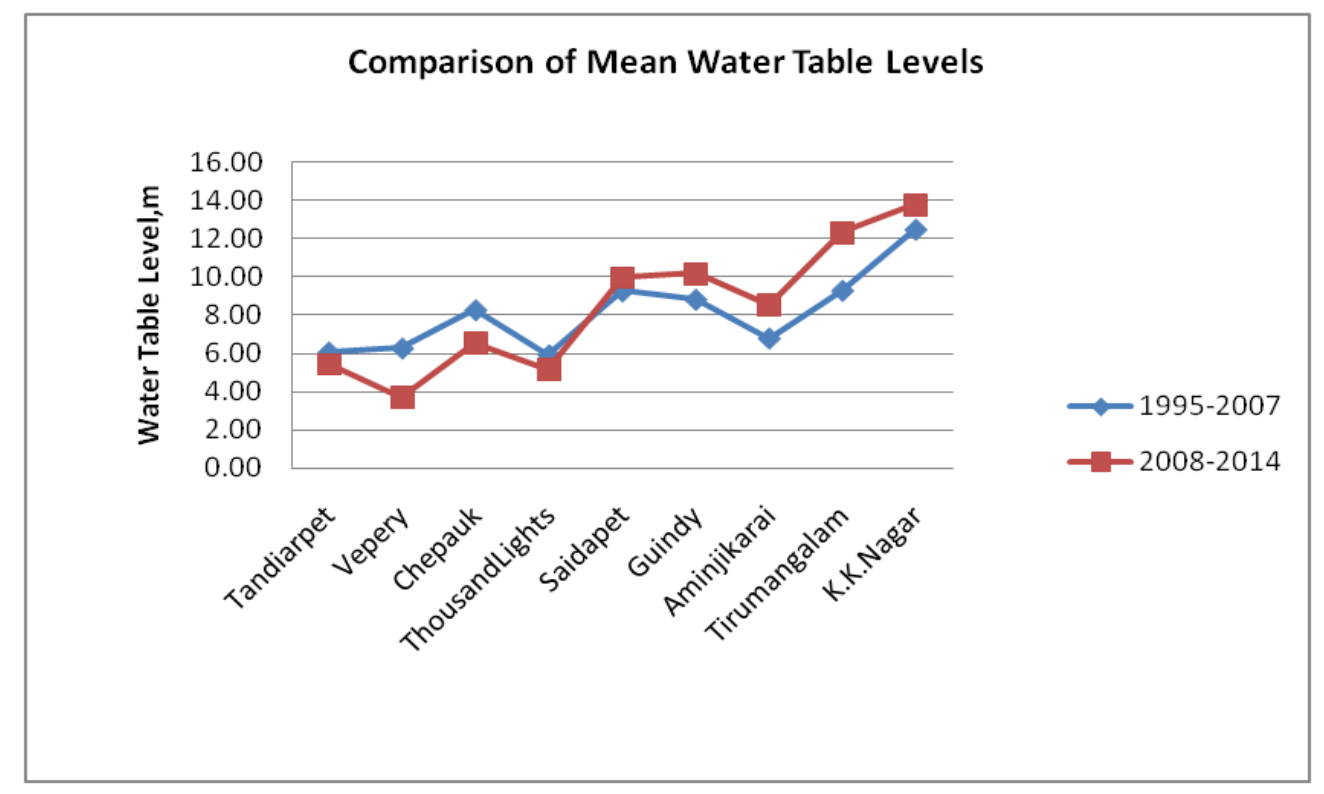

Graph 2. Comparison of mean water table values

\section{Soil map}

The soil map of the Chennai was collected and it was georeferenced and digitized for the study area. Within the study area, eight polygons were digitized for different types of soils present in the study area. The digitized soil map of the study area with types of soil available in the study area is shown in Figure 3. 
Table 2. Mean water table levels (1995-2001)

\begin{tabular}{c|c|c|c|c|c|c|c|c|c|c}
\hline & Latitude & Longitude & Elevation & $\mathbf{1 9 9 5}$ & $\mathbf{1 9 9 6}$ & $\mathbf{1 9 9 7}$ & $\mathbf{1 9 9 8}$ & $\mathbf{1 9 9 9}$ & $\mathbf{2 0 0 0}$ & $\mathbf{2 0 0 1}$ \\
\hline Tandiarpet & $13^{0} 07^{\prime} 38^{\prime \prime} \mathrm{N}$ & $80^{0} 17^{\prime} 24^{\prime \prime} \mathrm{E}$ & 9.98 & 6.54 & 6.39 & 6.80 & 6.76 & 5.36 & 5.70 & 5.48 \\
\hline Vepery & $13^{0} 05^{\prime} 07^{\prime \prime} \mathrm{N}$ & $80^{0} 15^{\prime} 38^{\prime \prime} \mathrm{E}$ & 10.13 & 9.17 & 7.48 & 6.09 & 5.87 & 7.49 & 5.54 & 4.05 \\
\hline Chepauk & $13^{0} 03^{\prime} 48^{\prime \prime} \mathrm{N}$ & $80^{0} 16^{\prime} 52^{\prime \prime} \mathrm{E}$ & 10.43 & 8.39 & 8.60 & 8.47 & 8.36 & 8.33 & 8.19 & 8.12 \\
\hline $\begin{array}{c}\text { Thousand } \\
\text { Lights }\end{array}$ & $13^{0} 03^{\prime} 32^{\prime \prime} \mathrm{N}$ & $80^{0} 15^{\prime} 05^{\prime \prime} \mathrm{E}$ & 11.52 & 6.77 & 5.37 & 6.79 & 7.11 & 5.39 & 5.70 & 5.44 \\
\hline Saidapet & $13^{0} 01^{\prime} 20^{\prime \prime} \mathrm{N}$ & $80^{0} 13^{\prime} 10^{\prime \prime} \mathrm{E}$ & 13.11 & 10.35 & 9.90 & 9.35 & 9.82 & 9.36 & 8.24 & 9.50 \\
\hline Guindy & $13^{0} 0^{\prime} 37^{\prime \prime} \mathrm{N}$ & $80^{0} 12^{\prime} 56^{\prime \prime} \mathrm{E}$ & 13.1 & 10.15 & 9.35 & 9.00 & 9.12 & 8.99 & 8.15 & 9.22 \\
\hline Aminjikarai & $13^{0} 04^{\prime} 12^{\prime \prime} \mathrm{N}$ & $80^{0} 13^{\prime} 28 \mathrm{E}$ & 14.12 & 7.96 & 6.40 & 7.12 & 6.68 & 7.08 & 5.29 & 14.12 \\
\hline $\begin{array}{c}\text { Tiruman } \\
\text { galam }\end{array}$ & $13^{0} 05^{\prime} 00^{\prime \prime} \mathrm{N}$ & $80^{0} 11^{\prime} 40^{\prime \prime} \mathrm{E}$ & 13.78 & 9.74 & 9.23 & 10.05 & 11.15 & 11.43 & 8.42 & 8.16 \\
\hline K. K. Nagar & $13^{0} 01^{\prime} 47^{\prime \prime} \mathrm{N}$ & $80^{0} 12^{\prime} 47^{\prime \prime} \mathrm{E}$ & 16 & 13.75 & 12.84 & 13.20 & 13.30 & 13.33 & 12.46 & 10.46 \\
\hline
\end{tabular}

Table 3. Mean water table levels (2002-2007)

\begin{tabular}{c|c|c|c|c|c|c|c|c|c|c}
\hline Location & Latitude & Longitude & Elevation & $\mathbf{2 0 0 2}$ & $\mathbf{2 0 0 3}$ & $\mathbf{2 0 0 4}$ & $\mathbf{2 0 0 5}$ & $\mathbf{2 0 0 6}$ & $\mathbf{2 0 0 7}$ & $\mathbf{M e a n}$ \\
\hline Tandiarpet & $13^{0} 07^{\prime} 38^{\prime \prime} \mathrm{N}$ & $80^{0} 17^{\prime} 24^{\prime \prime} \mathrm{E}$ & 9.98 & 5.90 & 5.26 & 5.98 & 3.96 & 7.37 & 6.94 & 6.03 \\
\hline Vepery & $13^{0} 05^{\prime} 07^{\prime \prime} \mathrm{N}$ & $80^{0} 15^{\prime} 38^{\prime \prime} \mathrm{E}$ & 10.13 & 6.60 & 7.23 & 5.04 & 4.96 & 5.92 & 5.75 & 6.24 \\
\hline Chepauk & $13^{0} 03^{\prime} 48^{\prime \prime} \mathrm{N}$ & $80^{0} 16^{\prime} 52^{\prime \prime} \mathrm{E}$ & 10.43 & 8.56 & 7.68 & 8.41 & 8.48 & 8.37 & 7.33 & 8.25 \\
\hline $\begin{array}{c}\text { Thousand } \\
\text { Lights }\end{array}$ & $13^{0} 03^{\prime} 32^{\prime \prime} \mathrm{N}$ & $80^{0} 15^{\prime} 05^{\prime \prime} \mathrm{E}$ & 11.52 & 6.40 & 5.20 & 5.51 & 5.65 & 5.60 & 5.62 & 5.89 \\
\hline Saidapet & $13^{0} 0120^{\prime \prime} \mathrm{N}$ & $80^{0} 13^{\prime} 10^{\prime \prime} \mathrm{E}$ & 13.11 & 11.30 & 11.99 & 8.74 & 6.71 & 6.75 & 8.12 & 9.24 \\
\hline Guindy & $13^{0} 0^{\prime} 37^{\prime \prime} \mathrm{N}$ & $80^{0} 12^{\prime} 56^{\prime \prime} \mathrm{E}$ & 13.1 & 10.95 & 11.12 & 8.25 & 6.13 & 5.96 & 8.05 & 8.80 \\
\hline Aminjikarai & $13^{0} 04^{\prime} 12^{\prime \prime} \mathrm{N}$ & $80^{0} 13^{\prime} 28^{\prime \prime} \mathrm{E}$ & 14.12 & 7.73 & 4.83 & 4.12 & 2.45 & 7.08 & 7.14 & 6.77 \\
\hline $\begin{array}{c}\text { Tiruman } \\
\text { galam }\end{array}$ & $13^{0} 05^{\prime} 00^{\prime \prime} \mathrm{N}$ & $80^{0} 11^{\prime} 40^{\prime \prime} \mathrm{E}$ & 13.78 & 9.20 & 8.51 & 6.11 & 7.67 & 9.77 & 11.13 & 9.28 \\
\hline K. K. Nagar & $13^{0} 01^{\prime} 47^{\prime \prime} \mathrm{N}$ & $80^{0} 12^{\prime} 47^{\prime \prime} \mathrm{E}$ & 16 & 13.07 & 11.76 & 8.97 & 10.67 & 14.22 & 14.29 & 12.49 \\
\hline
\end{tabular}

APPLIED ECOLOGY AND ENVIRONMENTAL RESEARCH 15(3):1801-1814.

http://www.aloki.hu • ISSN 15891623 (Print) • ISSN 17850037 (Online)

DOI: http://dx.doi.org/10.15666/aeer/1503_18011814

( 2017 , ALÖKI Kft., Budapest, Hungary 
Table 4. Mean water table levels (2008-2014)

\begin{tabular}{|c|c|c|c|c|c|c|c|c|c|c|c|}
\hline Location & Latitude & Longitude & Elevation & 2008 & 2009 & 2010 & 2011 & 2012 & 2013 & 2014 & Mean \\
\hline Tandiarpet & $13^{0} 07^{\prime} 38^{\prime \prime} \mathrm{N}$ & $80^{\circ} 17 ' 24 " \mathrm{E}$ & 9.98 & 7.03 & 6.05 & 5.12 & 5.47 & 5.01 & 5.46 & 3.78 & 5.42 \\
\hline Vepery & $13^{0} 05^{\prime} 07^{\prime \prime} \mathrm{N}$ & $80^{0} 15^{\prime} 38^{\prime \prime} \mathrm{E}$ & 10.13 & 4.19 & 3.71 & 3.63 & 4.15 & 3.18 & 3.46 & 3.41 & 3.68 \\
\hline Chepauk & $13^{0} 03^{\prime} 48^{\prime \prime} \mathrm{N}$ & $80^{0} 16^{\prime} 52^{\prime \prime} \mathrm{E}$ & 10.43 & 6.67 & 6.45 & 7.08 & 7.09 & 6.44 & 6.26 & 5.80 & 6.54 \\
\hline ThousandLights & $13^{0} 03^{\prime} 32^{\prime \prime} \mathrm{N}$ & $80^{0} 15^{\prime} 05^{\prime \prime} \mathrm{E}$ & 11.52 & 5.98 & 4.98 & 5.05 & 5.00 & 4.97 & 5.11 & 4.86 & 5.14 \\
\hline Saidapet & $13^{0} 011^{\prime} 20^{\prime \prime} \mathrm{N}$ & $80^{0} 13^{\prime} 10^{\prime \prime} \mathrm{E}$ & 13.11 & 14.62 & 8.16 & 8.97 & 8.33 & 9.86 & 9.92 & 9.85 & 9.96 \\
\hline Guindy & $13^{0} 0^{\prime} 37 " \mathrm{~N}$ & $80^{0} 12^{\prime} 56^{\prime \prime} \mathrm{E}$ & 13.1 & 8.76 & 10.05 & 11.27 & 11.50 & 9.96 & 8.60 & 10.92 & 10.15 \\
\hline Aminjikarai & $13^{0} 04^{\prime} 12^{\prime \prime} \mathrm{N}$ & $80^{0} 13^{\prime} 28^{\prime \prime} \mathrm{E}$ & 14.12 & 8.07 & 7.37 & 7.96 & 8.65 & 7.25 & 6.25 & 14.12 & 8.52 \\
\hline Tirumangalam & $13^{0} 05^{\prime} 00^{\prime \prime} \mathrm{N}$ & $80^{\circ} 11^{\prime} 40^{\prime \prime} \mathrm{E}$ & 13.78 & 11.84 & 11.70 & 12.94 & 12.96 & 12.38 & 10.49 & 13.82 & 12.30 \\
\hline K. K .Nagar & $13^{0} 01^{\prime} 47^{\prime \prime} \mathrm{N}$ & $80^{\circ} 12^{\prime} 47^{\prime \prime E}$ & 16 & 13.36 & 12.54 & 13.70 & 14.77 & 13.85 & 13.54 & 14.75 & 13.79 \\
\hline
\end{tabular}




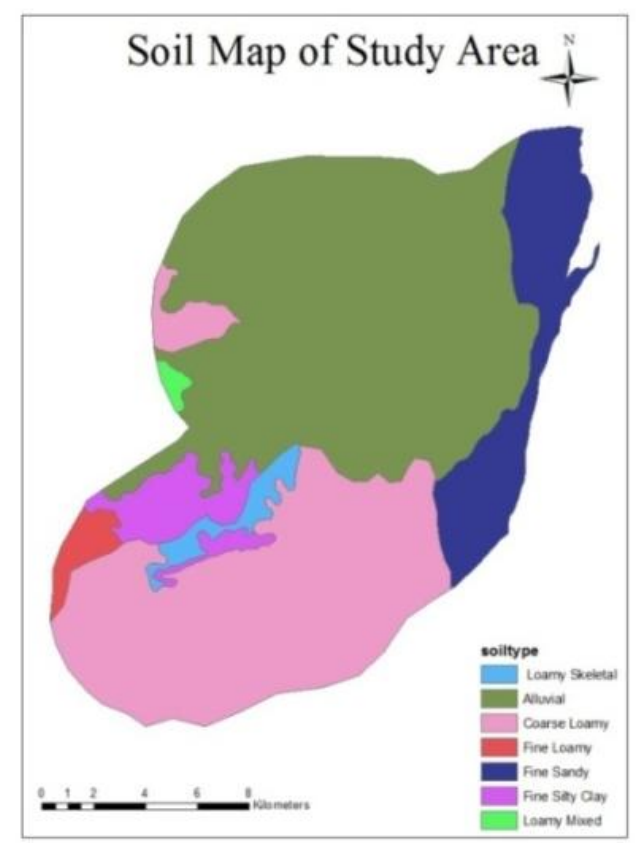

Figure 3. Soil map of study area

\section{Specific yield}

Specific yield is defined as the ratio of the volume of water that a saturated rock or soil yields due to gravity to the total volume of the rock or soil. Specific yield is usually expressed as a percentage. The value is not definitive, because the quantity of water that drains by gravity depends on variables such as duration of drainage, temperature, mineral composition of the water, and various physical characteristics of the rock or soil under consideration. Specific yield values for the various types of soils were identified and assigned to the respective polygons. Table 5 lists the types of soil and their specific yield values.

Table 5. Soil type and its specific yield

\begin{tabular}{c|c|c}
\hline Serial Number & Soil type & Specific yield (\%) \\
\hline 1 & Coarse loamy & $22 \%$ \\
\hline 2 & Alluvial & $26 \%$ \\
\hline 3 & Fine Sandy & $21 \%$ \\
\hline 4 & Loamy mixed & $19.6 \%$ \\
\hline 5 & Fine loamy & $16.4 \%$ \\
\hline 6 & Fine Silty Clay & $18 \%$ \\
\hline 7 & Loamy skeletal & $11.2 \%$ \\
\hline
\end{tabular}

\section{Quantification of water}

Rasterisation (or rasterization) is the task of taking up an image described in a vector graphics format (shapes) and converting it into a raster image (pixels or dots) for output on a video display or printer, or for storage in a bitmap file format. Soil map contains the specific yield values converted into raster data. Ground water volume is calculated by using the formula: 
where $S_{y}$ is the Specific yield (\%) that varies for different types of soils

$\mathrm{h}=$ Water table fluctuation , $\mathrm{m}$

A = Shape area of the study map

In the spatial analyst tool, raster calculator was used for calculating the volume of water. Weights were assigned on the basis of importance of the parameters. Since the water level is considered to be the predominant one to quantify, it is allotted with the weightage $70 \%, 20 \%$ for specific yield, $10 \%$ for the shape area.

Spatial distribution and the quantity of water were calculated for the mean values of each year and are tabulated in Table 6. The samples for the first phase (1995-2007) are shown in Figure 4 and Figure 5. Samples of spatial distribution for the second phase (2008-2014) are shown in Figure 6 and Figure 7.

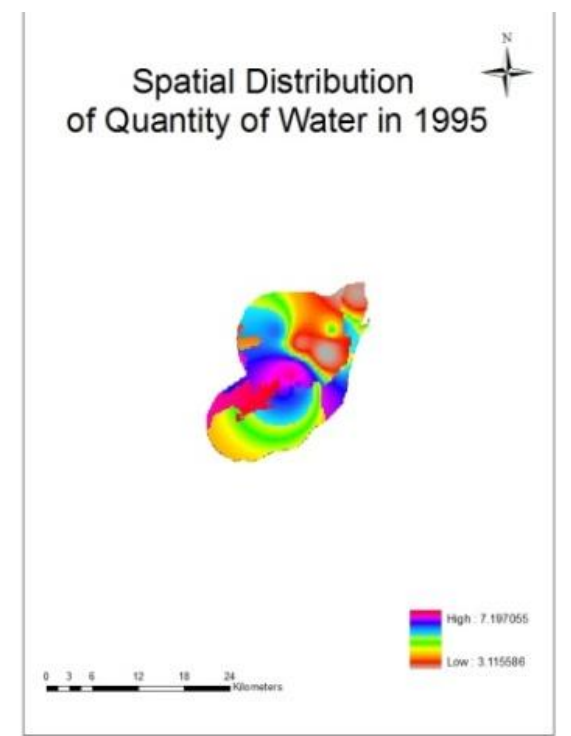

Figure 4. Spatial distribution of quantity of water in 1995

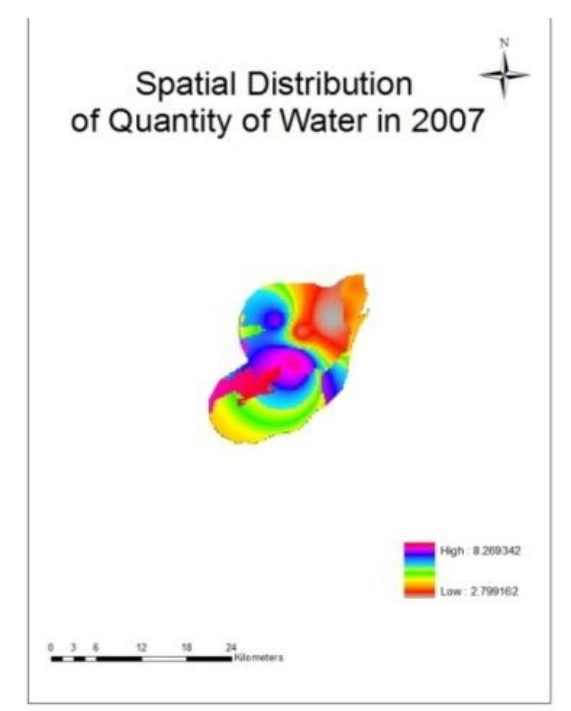

Figure 5. Spatial distribution of quantity of water in 2007 


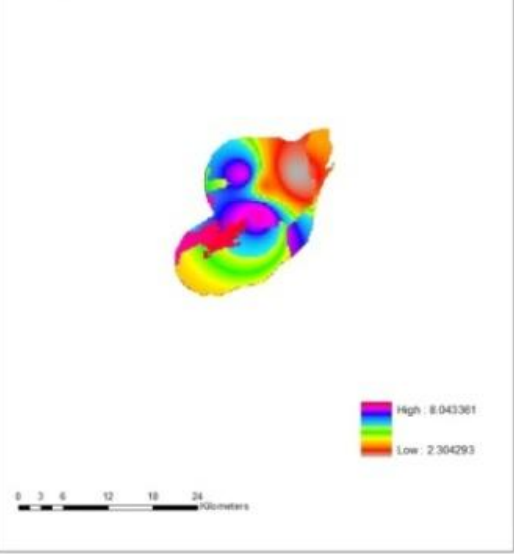

Figure 6. Spatial distributon of quantity of water in 2008

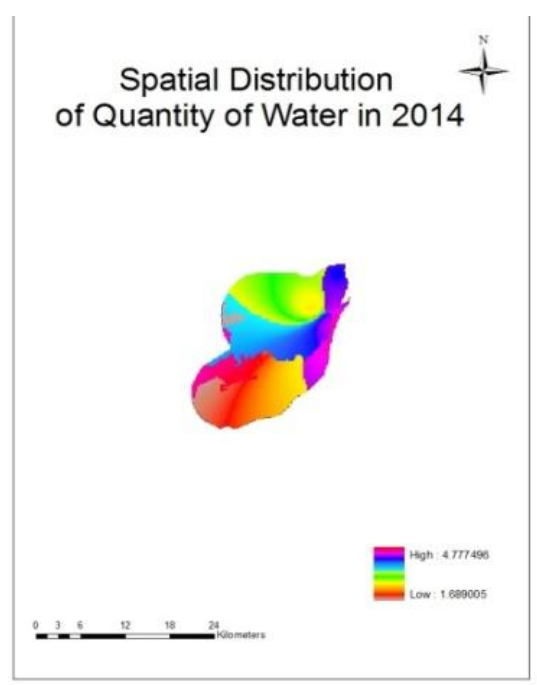

Figure 7. Spatial distributon of quantity of water in 2014

Table 6. Calculated water quantity range from 1995-2014

\begin{tabular}{c|c|c}
\hline Serial Number & Year & Water Quantity Range \\
\hline 1 & 1995 & $3.12-7.20$ \\
\hline 2 & 1996 & $2.66-7.46$ \\
\hline 3 & 1997 & $2.94-7.51$ \\
\hline 4 & 1998 & $2.85-7.60$ \\
\hline 5 & 1999 & $2.66-7.56$ \\
\hline 6 & 2000 & $2.62-7.14$ \\
\hline 7 & 2001 & $2.12-6.98$ \\
\hline 8 & 2002 & $3.05-7.69$ \\
\hline 9 & 2003 & $2.44-7.39$ \\
\hline 10 & 2004 & $2.15-6.34$ \\
\hline 11 & 2005 & $1.48-6.49$ \\
\hline 12 & 2006 & $2.87-8.23$ \\
\hline 13 & 2007 & $2.80-8.27$ \\
\hline
\end{tabular}




\begin{tabular}{l|l|l}
\hline 14 & 2008 & $2.30-8.04$ \\
\hline 15 & 2009 & $1.98-5.11$ \\
\hline 16 & 2010 & $1.95-5.12$ \\
\hline 17 & 2011 & $2.14-5.23$ \\
\hline 18 & 2012 & $1.77-4.94$ \\
\hline 19 & 2013 & $1.89-4.99$ \\
\hline 20 & 2014 & $1.69-4.78$ \\
\hline
\end{tabular}

The water quantity range calculated using the raster calculator from 1995-2014 was plotted as Graph 3. The graph clearly shows that both the low range and high range values after 2008, i.e., after the commencement of construction for the metro rail corridor.The quantity of water got reduced and the same scenario continued upto 2014 and the mean spatial distribution from 1995-2007 and 2008-2014 also confirms the same status and it is shown in Figure 8 and Figure 9.

Spatial distribution of the mean ground water volume calculated for the period 1995 2007 was found to be 2.98-7.37 for the study area. Similarly, the ground water volume got reduced to 1.98-5.44 during the period 2008-2014, i.e., after the construction of metro rail.

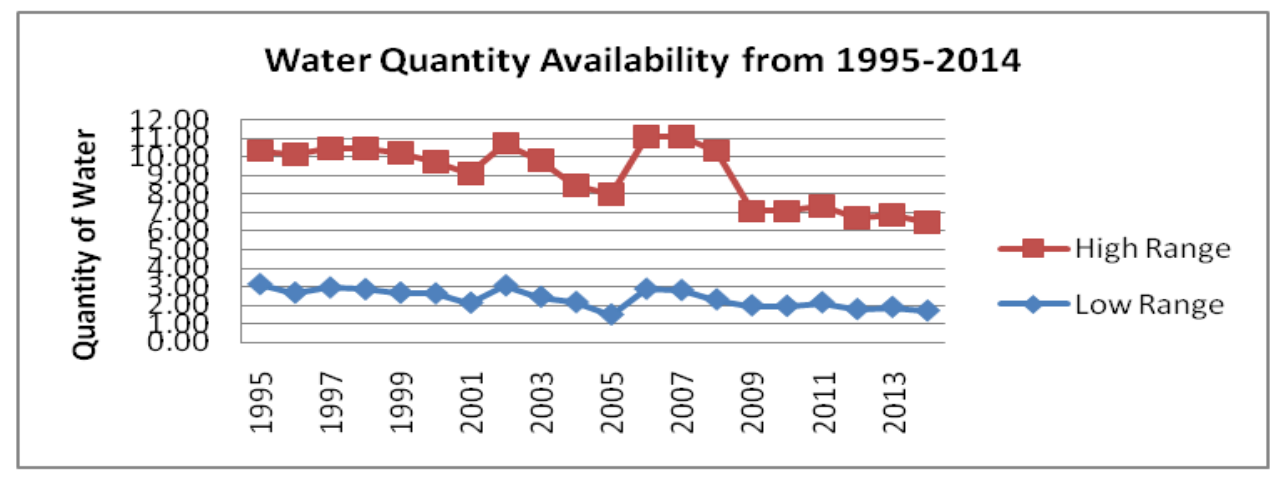

Graph 3. Water quantity availability from 1995-2014

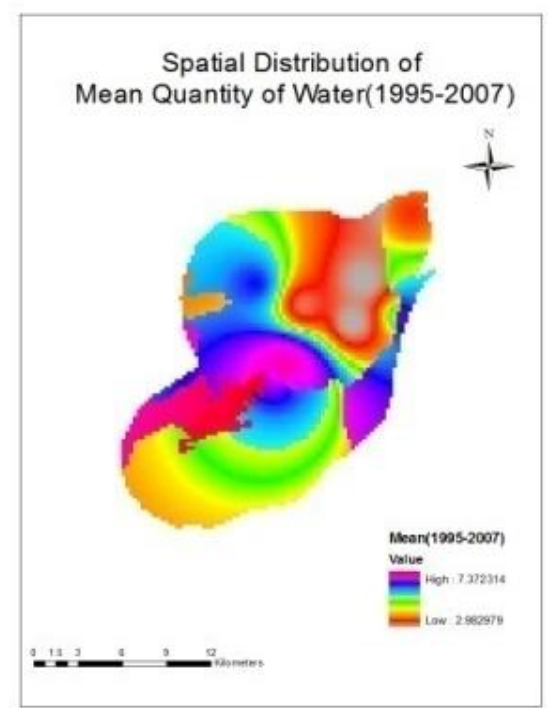

Figure 8. Spatial distribution of quantity of water in 1995-2007 


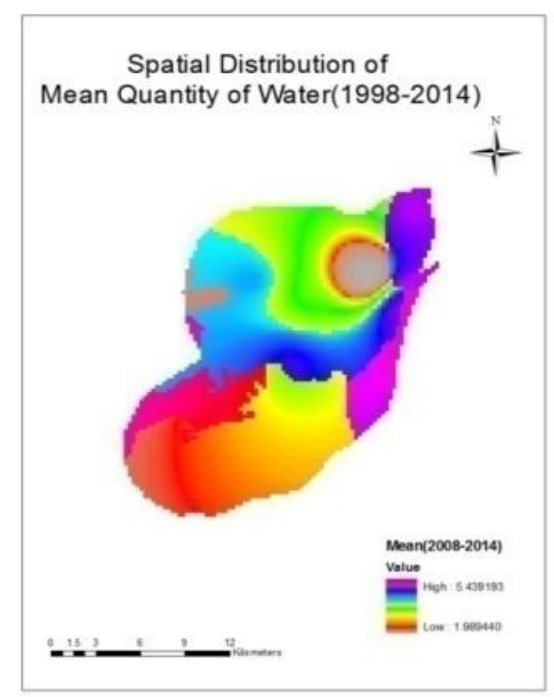

Figure 9. Spatial Distribution of Quantity of Water in 2008-2014

\section{Conclusion}

Reduction in ground water volume was due to the underground development around the metro rail corridors. This was clearly shown from the calculation of ground water volume using raster calculator in GIS. The mean water table levels were found to be decreased in Tondiarpet, Vepery, Chepauk, whereas increased water table levels were found in Guindy, Saidapet, Aminjikarai, Tirumangalam and K. K. Nagar. This may be due to the slope disturbance created by the underground development. The plotted graphs clearly show that the Rainfall cannot be seen as the parameter which changes the water table levels and the massive underground construction seems to be the major cause for the reduction in water levels.

\section{REFERENCES}

[1] Bonansea, M., Ledesma, C., Rodriguez, M. C. (2016): Assessing the impact of land use and land cover on water quality in the watershed of a reservoir. - Applied Ecology and Environmental Research 14(2): 447-456.

[2] Cui, H., Liu, J., Gao, C., Yu, F. (2009): Urban water sustainable utilization. - $3^{\text {rd }}$ International Conference on Bioinformatics and Biomedical Engineering. Beijing, China.

[3] Goodchild, M. F., Parks, B. O., Steyaert, L. T. (1993): Environmental modelling with GIS.- Oxford University Press, New York.

[4] Han, M., Tian, X., Xu, S. (2005): Research on data collection and database update of GIS based on GPS technology. - International Geoscience and Remote Sensing Symposium 2:0. Seoul, South Korea.

[5] Jasmin, I., Mallikarjuna, P. (2015): Delineation of groundwater potential zones in Araniar River basin, Tamil Nadu, India: an integrated remote sensing and geographical information system approach: - Environmental Earth Sciences 73(7): 3833-3847.

[6] Jat, M. K., Khare, D., Garg, P. K. (2005): Integrated water management in urban areas: ecological and economic advantages. - Journal of Indian Building Congress 12(1):186193.

[7] Jat, M. K., Khare, D., Garg, P. K. (2009): Urbanization and its impact on groundwater: a remote sensing and GIS-based assessment approach. - Environmentalist 29: 17-32. 
[8] Navarro-Solís, O., González-Trinidad, J., Júnez-Ferreira, H. E., Cardona, A., BautistaCapetillo, C. F. (2016): Integrative methodology for the identification of groundwater flow patterns: application in a semi-arid region of Mexico. - Applied ecology and environmental research 14(4): 645-666.

[9] Rahman, M. D., Mahbub, A. Q. M. (2012): Groundwater Depletion with Expansion of Irrigation in Barind Tract: A Case Study of Tanore Upazila. - Journal of Water Resource and Protection 4: 567-575.

[10] Rajamanickam, R., Nagan, S. (2010): Groundwater Quality Modeling of Amaravathi River Basin of Karur District,Tamil Nadu, Using Visual Modflow. - International Journal of Environmental Sciences 1(1): 91-108.

[11] Ravikumar, G., Shahidhar, T., Krishnaveni, M., Karunakaran, K. (2005): GIS Based Ground Water Quantity Assessment Model. - International Journal of Civil and Environmental Engineering 1(2): 21-30.

[12] Riad, P. H. S., Billib, M., Hassan, A. A., Salam, M. A., Din, M. N. E. (2011): Application of the overlay weighted model and boolean logic to determine the best locations for artificial recharge of groundwater. - Journal of Urban and Environmental Engineering 5(2): 57-66.

[13] Shukla, S. M. (2014) : Spatial Analysis for Groundwater Potential Zones using GIS and Remote Sensing in the Tons Basin of Allahabad District, Uttar Pradesh, India: Proceedings of the National Academy of Sciences, India Section A: Physical Sciences 84(4): 587-593.

[14] Wang, J., Yin, K., Chen, J. (2011): Research and Realization of the Groundwater Analyze Module Based on MapGIS. $-19^{\text {th }}$ International Conference on Geoinformatics. Shanghai, China.

[15] Wei, J., Wang, G., Li., Shao, J. (2003):Application of GIS in groundwater research. Hydrogeology and Engineering Geology 94-97.

[16] Yoo, C.,Kim, S. B., Lee, Y. J., Kim, S. H., Kim, T. (2007): Interaction between tunelling and ground water. Its impact on tunnel behaviour and ground settlement - underground space $-4^{\text {th }}$ dimension of metropolises. - Taylor and Francis group, London. 